\title{
ANALISIS PERTUMBUHAN Sargassum sp. DENGAN SISTEM BUDIDAYA YANG BERBEDA DI TELUK EKAS LOMBOK TIMUR SEBAGAI BAHAN PENGAYAAN MATA KULIAH EKOLOGI TUMBUHAN
}

\author{
Muhammad Lutfiawan'), Karnan ${ }^{2)}$, Lalu Japa ${ }^{3)}$ \\ ${ }^{1)}$ Mahasiswa Pendidikan Biologi FKIP Universitas Mataram \\ 2) 3) Dosen Pendidikan Biologi FKIP Universitas Mataram \\ Universitas Mataram, Jalan Majapahit No.62, Mataram \\ Email: muhammad_lutfiawan@yahoo.co.id
}

\begin{abstract}
ABSTRAK
Tujuan dari penelitian ini adalah untuk mengetahui perbedaan pertumbuhan Sargassum sp. yang dibudidaya dengan sistem budidaya yang berbeda di Teluk Ekas Lombok Timur. Jenis penelitian ini adalah penelitian eksperimen.. Sampel dalam penelitian ini adalah tanaman Sargassum sp yang dibudidayakan dengan sistem budidaya yang berbeda yaitu : rakit terapung dan rakit patok dasar. Pengolahan data dilakukan dengan menggunakan paket program komputer pengolahan data yaitu SPSS 16. Pengujian hipotesis dilakukan dengan menggunakan uji-t polled varians, dengan taraf signifikan 0,05 dan taraf kepercayaan $95 \%$, diperoleh t-hitung 11,974>t-tabel 1,987, atau berdasarkan besarnya nilai probabilitas yang ditunjukan, diperoleh probabilitas-hitung $0,00<$ probabilitas-tabel 0,05, sehingga Ho ditolak dan Ha diterima, ini artinya terdapat perbedaan pertumbuhan Sargassum sp. yang dibudidaya dengan sistem budidaya yang berbeda.
\end{abstract}

\section{Kata-kata kunci: $\quad$ Sargassum sp., Teluk Ekas, Sistem budidaya yang berbeda.}

\begin{abstract}
The purpose of this research is to determine growth differences of Sargassum sp., were cultured with different cultivation systems in the Ekas Bay of East Lombok. This research is an experimental research. The sample in this research is Sargassum sp. of cultivated crops with different cultivation systems, such as : floating raft and raft basic stakes. Processing date was performed by using a processing date computer program package SPSS 16. Hypothesis testing is done by using t-test polled variance, with a significance level of 0.05 and a level of valid $95 \%$, in order to obtain $\mathrm{t}$ count $11.974>\mathrm{t}$ - table 1,987 , or based on the value of the indicated probability, probability-count obtained $0.00<0.05$ probability- table, so that Ho is rejected and $\mathrm{Ha}$ accepted, this means that there are differences in the growth of Sargassum sp. were cultured with different cultivation systems.
\end{abstract}

Key words: Sargassum sp., Ekas bay, Different Cultivation System. 


\section{PENDAHULUAN}

Sargassum sp. merupakan alga coklat yang hidup pada habitat karang dengan kedalaman 0,5-10 meter. Anggadiredja (2006) menjelaskan bahwa Sargassum adalah salah satu genus dari kelompok rumput laut coklat yang merupakan genera terbesar dari family Sargassaceae.

Guiry (2007) menjelaskan bahwa Sargassum sp. adalah rumput laut yang tergolong Divisi Phaeophyta (ganggang coklat). Spesies ini dapat tumbuh sampai panjang 12 meter. Tubuhnya berwarna cokelat kuning kehijauan, dengan struktur tubuh terbagi atas sebuah holdfast yang berfungsi sebagai struktur basal, sebuah stipe atau batang semu, dan sebuah frond yang berbentuk seperti daun. Warna coklat pada alga divisi Phaeophyta muncul akibat dominansi dari pigmen fucoxanthin, klorofil a dan c, betakaroten, dan xantofil lainnya. Karbohidrat yang disimpan sebagian besar tersedia dalam bentuk laminaran (polisakarida glukosa; terbentuk dari proses fotosintesis), disertai dengan pati dalam jumlah tertentu tergantung spesiesnya. Dinding selnya terbuat dari selulosa dan asam alginat. Anggadiredja et al. (2008) menjelaskan bahwa Sargassum sp. memiliki bentuk thallus gepeng, banyak percabangan yang menyerupai pepohonan di darat, bangun daun melebar, lonjong seperti pedang, memiliki gelembung udara yang umumnya soliter, batang utama bulat agak kasar, dan holdfast (bagian yang digunakan untuk melekat) berbentuk cakram, pinggir daun bergerigi jarang, berombak, dan ujung melengkung atau meruncing.

Sargassum sp. juga berperan penting dalam ekosistem. Kadi (2005). Ia menjelaskan bahwa secara ekologis alga
Sargassum ikut andil dalam pembentukan ekosistem terumbu karang dan merupakan tempat asuhan bagi biota kecil, termasuk untuk perlindungan benih ikan dan benur udang serta sarang melekatnya telur cumicumi.

Rachmat (1999) menjelaskan bahwa Sargassum merupakan alga coklat yang terdiri dari kurang lebih 400 jenis di dunia. Jenis-jenis Sargassum yang dikenal di Indonesia ada sekitar 12 spesies, yaitu : Sargassum duplicatum, Sargassum histrix, Sargassum echinocarpum, Sargassum gracilimun, Sargassum obtusifolium, Sargassum binderi, Sargassum policystum, Sargassum crassifolium, Sargassum microphylum, Sargassum aquofilum, Sargassum vulgare, dan Sargassum polyceratium.

$$
\text { Bold dan Wynne }
$$

menjelaskan bahwa perkembangbiakan atau reproduksi marga Sargassum yang termasuk bangsa Fucales, marga Sargassaceae dikenal dua cara yaitu: Reproduksi asexual (vegetatif) dan sexual (generatif). Reproduksi vegetatif dilakukan melalui fragmentasi yaitu potongan thallus berkembang melakukan pertumbuhannya. Cara ini banyak dilakukan untuk usaha budidaya. Reproduksi generatif yaitu perkembangan individu melalui organ jantan (antheridia) dan organ betina (oogenia) . Boney (1965) menjelaskan bahwa lingkungan tempat tumbuh alga Sargassum sp. terutama di daerah perairan yang jernih yang mempunyai substrat dasar batu karang, karang mati, batuan vulkanik dan bendabenda yang bersifat masif yang berada di dasar perairan. Alga Sargassum sp. tumbuh dari daerah intertidal, subtidal sampai daerah tubir dengan ombak besar dan arus deras. 
Kedalaman untuk pertumbuhan dari 0,5 -10 m. Marga Sargassum sp. termasuk dalam kelas Phaeophyceae tumbuh subur pada daerah tropis, suhu perairan $27,25-29,30{ }^{\circ} \mathrm{C}$ dan salinitas 32 - 33,5 \%o. Kebutuhan intensitas cahaya matahari marga Sargassum sp. lebih tinggi dari pada marga algae merah. Pertumbuhan Sargassum sp. mebutuhkan intensitas cahaya matahari berkisar 6500 7500 lux. Alga Sargassum sp. tumbuh berumpun dengan untaian cabang-cabang. Panjang thallus utama mencapai 1 - $3 \mathrm{~m}$ dan tiap-tiap percabangan terdapat gelembung udara berbentuk bulat yang disebut "Bladder," berguna untuk menopang cabangcabang thallus terapung ke arah permukaan air untuk mendapatkan intensitas cahaya matahari. Kehadiran alga Sargassum sp. tumbuh di bentangan perairan pantai di zona paparan terumbu (reef flats) mulai dari garis pantai sampai ujung tubir termasuk dalam perairan intertidal dan subtidal.

\section{Perburuan kerang dan} pemangkasan liar oleh masyarakat sekitar Batunampar di Teluk Ekas membuat terkikisnya substrat-substrat tempat menempelnya Sargassum sp., lama kelamaan habitat padang Sargassum sp. tersebut akan hilang. Untuk itu masyarakat perlu kesadaran untuk ikut andil dalam menjaga kelestarian habitat padang Sargassum ini, mengingat perannya dalam melindungi ekosistem atau tempat hidupnya biota-biota laut. Menurut Hak dan Tazwir (2004) Salah satu usaha untuk penyediaan bahan baku rumput laut coklat adalah melakukan budidaya secara intensif, untuk mencukupi kebutuhan rumput laut coklat yang tiap tahun selalu bertambah. Untuk mengantisipasi pemenuhan kebutuhan rumput laut coklat masa yang akan datang, maka dilakukan suatu penelitian tentang budidaya rumput laut coklat menggunakan rakit. Disamping itu dilakukan juga suatu penelitian yang berhubungan dengan kandungan Na-alginat dari rumput laut coklat berdasarkan umur panen rumput laut coklat tersebut. Hal ini penting karena kadar Na-alginat ada hubungannya dengan umur panen dari rumput laut coklat tersebut sehingga dapat ditentukan kapan rumput laut coklat harus dipanen yang menghasilkan sifat fisika kimia dari Na-alginat yang memenuhi standar perdagangan

Kebutuhan Sargassum sp. akan sinar matahari dalam berfotosintesis sangat diperlukan. Intensitas dan kualitas sinar matahari yang ada di dasar dengan permukaan perairan sangatlah berbeda, dimana intensitas dan kualitas sinar matahari pada permukaan perairan lebih tinggi daripada pada dasar perairan. Untuk itu akan dilakukan penanaman menggunakan dua sistem rakit yaitu rakit patok dasar dan rakit terapung. Dalam pembudidayaan ini diharapkan adanya perbedaan kecepatan tumbuh, khususnya pada rakit terapung yang memiliki ketersediaan sinar matahari yang lebih tinggi maka kecepatan tumbuhnya akan menjadi lebih cepat daripada pada rakit lepas dasar. Seperti yang dijelaskan oleh Msuya dan Neori (2002) menjelaskan bahwa makroalga memiliki kemampuan untuk berfotosintesis, mengubah energi dari matahari menjadi energi yang dapat digunakan sebagai makanan.

\section{METODE PENELITIAN}

Jenis penelitian ini adalah penelitian eksperimen. Metode yang digunakan dalam penelitian ini adalah sample survey method atau survei di lapangan.

Sampel penelitian ini adalah tanaman Sargassum sp. yang dibudidayakan di dalam rakit yang berbeda. Penelitian ini menggunakan dua sistem budidaya yaitu 
rakit lepas dasar yang diikat dibatu pada dasar perairan dan rakit terapung yang diikat di rakit pada permukaan perairan dengan jarak tanam masing-masing bibit yaitu $20 \mathrm{~cm}$. Jenis rumput laut yang digunakan yaitu Sargassum sp. dengan berat awal 20 gr).

Dalam penelitian langkah-langkah dalam pembudidayaan juga berperan penting demi menghindari masalah yang tidak terduga. Adapun langkah-langkah yang dilakukan dalam pembudidayaan meliputi : 1) Persiapan penanaman, 2) Penanaman, 3) Pemeliharaan dan 4) Pemanenen.

\section{Persiapan Penanaman}

Tahap persiapan penanaman merupakan tahap untuk menyiapkan bibitbibit yang telah kita seleksi dan disiapkan untuk ditanam dengan ukuran tertentu. Persiapan dalam penanaman memiliki tiga kegiatan yakni : pengambilan, penimbangan bibit dan pengikatan bibit.

\section{a. Pengambilan Bibit}

Sargassum sp. yang digunakan sebagai bibit diperoleh dari Sargassum sp. liar yang ada di lokasi penelitian, bibit tersebut ditemukan berbentuk suatu rumpun besar yang lengkap dengan bagian-bagiannya. Bibit tersebut sangat mudah ditemukan walaupun tumbuh pada kedalaman \pm 1 meter, karena bagian thallus selalu mengapung pada permukaan perairan. Bibit yang telah dikumpulkan selanjutnya ditimbang .

\section{b. Penimbangan Bibit}

Bibit yang telah dikumpulkan selanjutnya ditimbang dengan berat 20 gram/rumpun menggunakan timbangan gram. Bibit yang telah ditimbang selanjutnya disiapkan sebanyak 140 rumpun, dimana 70 rumpun diikat pada patok dasar dan 70 rumpun sisanya diikat pada rakit terapung.

\section{c. Pengikatan bibit}

Bibit yang telah disiapkan selanjutnya diikat pada tali yang telah disiapkan. Dalam hal ini terdapat dua utas tali nilon dengan panjang masing-masing 15 meter untuk kedua sistem budidaya. Tali nilon dengan tali ikat berwarna kuning untuk patok dasar dan tali nilon dengan tali ikat berwarna merah untuk rakit terapung, pada masing-masing tali terikat 70 rumpun bibit Sargassum sp.

\section{Penanaman Bibit}

Penanaman bibit merupakan tahap kedua yakni pelaksanaan penanaman. Bibit yang sudah diikat pada kedua tali nilon selanjutnya akan diikat pada rakit (untuk yang terapung) dan akan dibenamkan pada dasar perairan (untuk yang patok dasar). Untuk patok dasar kita gunakan batu sebagai patoknya, karena batu lebih tahan terhadap kecepatan arus daripada menggunakan besi atau kayu, sedangkan untuk rakit terapung dapat langsung kita ikat pada rakit.

\section{Pemeliharaan}

Untuk mencegah terjadinya hal yang tidak diinginkan terkait pertumbuhan sargassum, maka perlu dilakukannya pemeliharaan. Adapun hal-hal yang dilakukan selama pemeliharaan antara lain seperti menyingkirkan rumput-rumput laut penggangu seperti jenis Gillidium sp. dan Fillamenteus algae, mngecek tali rafia pengikat rumpun serta mencegah orang agar tidak mengganggu peneltian ini.

\section{Pemanenan Sargassum sp.}

Sargassum sp. setelah berumur 30 hari dipanen dan dilakukan penimbangan untuk mengetahui berapa pertambahan massa dari Sargassum sp. dari berat awal tanam ratarata 20 gr sampai berat akhir pada saat panen. 


\section{HASIL DAN PEMBAHASAN}

Sampel yang telah dipanen dalam rakit selanjutnya ditimbang pertambahan massanya dan untuk pengumpulan data dapat diformulasikan dalam Gambar 1 perbandingan pertumbuhan Sargassum sp. antara sistem budidaya patok dasar dengan rakit terapung.

Tabel 1. Kondisi lingkungan di Teluk Ekas Desa Batunampar Kecamatan Jerowaru Lombok Timur.

\begin{tabular}{clc}
\hline No. & \multicolumn{1}{c}{ Variabel } & Nilai \\
\hline 1 & Salinitas $(\%)$ & 5,67 \\
2 & Suhu $\left({ }^{\circ} \mathrm{C}\right)$ & $29-30$ \\
3 & pH & 7,4 \\
4 & Kedalaman maksimal & 2,5 \\
& $(\mathrm{~m})$ & Pasir \\
5 & Substrat & lumpur \\
\hline
\end{tabular}

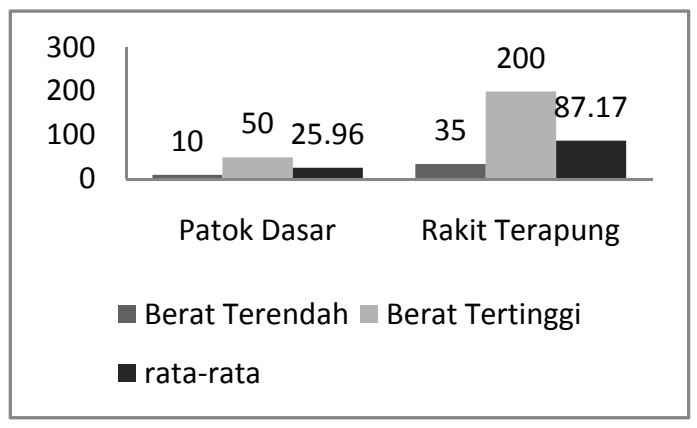

Gambar 1. Grafik perbandingan pertumbuhan Sargassum sp. antara sistem budidaya patok dasar dengan rakit terapung.

Berdasarkan (Gambar 1) kecepatan tumbuh, berat terkecil dari patok dasar adalah 10 gram sedangkan pada rakit terapung 35 gram dan untuk berat terbesarnya, pada patok dasar mencapai 50 gram sedangkan rakit terapung 200 gram
(Gambar 1). Intensitas cahaya pada patok dasar lebih rendah daripada rakit terapung. Pada patok dasar saat kondisi pasut naik, kedalaman air bisa mencapai 2,5-3 meter sedangkan pada saat pasut normal, kedalamannya 1-1,5 meter. Sedangkan pada rakit terapung kedalaman airnya selalu sama yakni 0 meter, artinya tidak terpengaruh oleh keadaan pasut. Karena perbedaan kualitas cahya inilah yang menyebabkan berat perrumpun pada patok dasar jauh lebih rendah daripada rakit terapung. Pada awal penanamannya berat rata-rata 20 gram untuk patok dasar dan rakit terapung dan setelah diamati selama 30 hari berat rata-rata Sargassum sp. yang dibudidaya pada rakit terapung menjadi 87,17 gram, dibandingkan dengan patok dasar dengan berat 25,96 gram.

Berdasarkan dari data pertumbuhan Sargassum sp. Hasil pengamatan menunjukan, bahwa pada budidaya menggunakan patok dasar dari total 70 rumpun yang ditanam hanya 47 yang hidup dan 23 dinyatakan hilang. Hal ini dikarenakan terjadinya proses pengadukan pada substrat berlumpur yang dikarenakan kecepatan arus pada dasar perairan lebih kuat daripada di permukaan perairan, sehingga lumpur menutupi seluruh bagian tanaman termauk tali penanaman, selain itu karena pengaruh kurang kuatnya ikatan rumpun pada tali penanaman. 
Tabel 2. Output analisis data perbedaan pertumbuhan Sargassum sp. di Teluk Ekas Lombok Timur dengan menggunakan SPSS 16.

\section{Bagian 1.}

\begin{tabular}{|cc|c|c|c|c|}
\hline & Group Statistics \\
\hline & Sistem & $\mathrm{N}$ & Mean & $\begin{array}{c}\text { Std. } \\
\text { Deviation }\end{array}$ & $\begin{array}{c}\text { Std. Error } \\
\text { Mean }\end{array}$ \\
\hline pertumbuhan & Dasar & 47 & 25.957 & 10.1958 & 1.4872 \\
& Permukaan & 69 & 87.174 & 33.9818 & 4.0909 \\
\hline
\end{tabular}

\section{Bagian 2}

\begin{tabular}{|c|c|c|c|c|c|c|c|c|c|c|}
\hline \multicolumn{11}{|c|}{ Independent Samples Test } \\
\hline & & \multicolumn{2}{|c|}{$\begin{array}{l}\text { Levene's } \\
\text { Test for } \\
\text { Equality of } \\
\text { Variances }\end{array}$} & \multicolumn{7}{|c|}{ t-test for Equality of Means } \\
\hline & & \multirow[t]{2}{*}{$\mathrm{F}$} & \multirow[t]{2}{*}{ Sig. } & \multirow[t]{2}{*}{$\mathrm{T}$} & \multirow[t]{2}{*}{ Df } & \multirow[t]{2}{*}{$\begin{array}{l}\text { Sig. (2- } \\
\text { tailed) }\end{array}$} & \multirow[t]{2}{*}{$\begin{array}{c}\text { Mean } \\
\text { Difference }\end{array}$} & \multirow[t]{2}{*}{$\begin{array}{l}\text { Std. } \\
\text { Error } \\
\text { Differe } \\
\text { nce }\end{array}$} & \multicolumn{2}{|c|}{$\begin{array}{c}95 \% \\
\text { Confidence } \\
\text { Interval of the } \\
\text { Difference }\end{array}$} \\
\hline & & & & & & & & & Lower & Upper \\
\hline $\begin{array}{l}\text { Pertum } \\
\text { buhan }\end{array}$ & $\begin{array}{l}\text { Equal } \\
\text { variances } \\
\text { assumed }\end{array}$ & 22.803 & .000 & 11.974 & 114 & .000 & -61.2165 & 5.1126 & $\begin{array}{c}- \\
71.34 \\
45\end{array}$ & $\begin{array}{c}- \\
51.088 \\
5\end{array}$ \\
\hline
\end{tabular}

Berdasarkan dari hasil analisis data (Tabel 2). Pada bagian 1 terlihat bahwa jumlah sampel (n) tidak sama dimana yang dibudidaya di dasar perairan berjumlah 47 rumpun, sedangkan yang di peremukaan (rakit terapung) berjumlah 69 rumpun. Dari hasil ini terlihat adanya perbedaan rataan yang mencolok diantara keduanya, yaitu 25,957 gram/rumpun untuk yang dibudidaya di dasar perairan dan 87,174 gram/rumpun untuk yang dibudidaya secara terapung. Pada bagian 2 terlihat bahwa probabilitasnya 0,000 . Oleh karena probabilitasnya $<0,05$ maka Ho ditolak, atau kedua varians benar- benar berbeda. Dan untuk uji t diperoleh hasil untuk t-hitung 11,974> t-tabelnya 1,981, maka Ha diterima. Ini berarti terdapat perbedaan kecepatan tumbuh antara sistem budidaya patok dasar dengan rakit terapung.

Adapun faktor-faktor yang berperan penting dalam kecepatan tumbuh Sargassum adalah Intensitas cahaya dan kecepatan arus. Patok dasar cenderung substratnya lebih mudah keruh karena terjadinya proses pengadukan sebagai akibat dari kuatnya arus di dasar perairan. Disamping itu juga karena rendahnya intensitas cahaya menyebabkan 
kemampuan fotosintesisnya jadi lebih rendah. Apabila dibandingkan dengan rakit terapung, tentu saja rakit terapung lebih unggul dalam hal intensitas cahaya karena berhadapan langsung dengan cahaya matahari dan lambatnya kecepatan arus dan tidak bersubstrat pasir berlumpur menjadikan sistem budidaya ini jauh lebih efektif daripada sistem budidaya patok dasar. Hal ini sesuai dengan peryataan Aslan (1998) mengatakan bahwa rumput laut memerlukan cahaya matahari untuk proses fotosintesisnya. Karena itu, rumput laut hanya mungkin tumbuh diperairan dengan kedalaman tertentu dimana sinar matahari sampai ke dasar perairan. Indriani (1991) menjelaskan bahwa kondisi perairan pantai tempat tumbuh rumput laut tidak boleh keruh, karena apabila kondisi perairannya keruh maka akan dapat menghalangi proses fotosintesis dari rumput laut. Air harus jernih sehingga tidak menghalangi sinar matahari menembus air laut.

Sargassum sp. dapat tumbuh di daerah Teluk Ekas Kecamatan Jerowaru Lombok Timur karena kondisi lingkungan mendukung untuk pertumbuhannya. Daerah ini memiliki kawasan pasang surut yang terbuka dan memiliki substrat pasir berlumpur serta kedalaman hanya mencapai 2,5 meter saat pasang maksimal. Hal ini sesuai dengan pernyataan Atmadja dan Soelistijo (1980) bahwa pada umumnya Sargassum tumbuh di daerah terumbu karang (coral reef) seperti di Kepulauan Seribu, terutama di daerah rataan pasir (sand flat). Daerah ini akan kering pada saat surut rendah, mempunyai dasar berpasir dan terdapat pula pada karang hidup atau mati. Pada batu-batu ini tumbuh dan melekat rumput laut coklat.

Pada musim-musim tertentu wilayah teluk akan mengalami surut yang bahkan tinggi air hanya mencapai $5 \mathrm{~cm}$, dalam keadaan demikian para masyarakat seringkali melakukan perburuan kerang dan rumput laut yang biasa disebut dengan madak. Boney (1965) mengatakan bahwa karakteristik biologi rumput laut Sargassum crassifolium (alga coklat) hidup dan tumbuh di daerah pesisir pantai dengan substrat batu karang. Sargassum crassifolium tumbuh di daerah intertidal, subtidal sampai daerah dengan ombak besar dan arus yang deras. Alga ini tumbuh pada daerah tropis dengan suhu 27-30 ${ }^{\circ} \mathrm{C}$, salinitas 32-33 ppt dan kedalaman 0,5-10 m. Menurut Hak dan Tazwir [2004] mengatakan bahwa selama dilakukan budidaya rumput laut coklat, diamati media tumbuh rumput laut coklat tersebut, suhu air laut rata- rata $29{ }^{\circ} \mathrm{C}$, kecepatan angin 5/min - 5,4/min dan suhu udara 32-35 ${ }^{\circ} \mathrm{C}$. Berdasarkan keadaan wilayah Teluk Ekas, kisaran suhunya antara 29-30 ${ }^{\circ} \mathrm{C}$, artinya suhu tersebut merupakan suhu yang dikatakan masih optimal dalam upaya pembudidayaan Sargassum sp. khususnya dan rumput laut secara umum.

Adapun faktor-faktor yang berperan penting dalam kecepatan tumbuh Sargassum adalah Intensitas cahaya dan kecepatan arus. Patok dasar cenderung substratnya lebih mudah keruh karena terjadinya proses pengadukan sebagai akibat dari kuatnya arus di dasar perairan. Disamping itu juga karena rendahnya intensitas cahaya menyebabkan kemampuan fotosintesisnya jadi lebih rendah. Apabila dibandingkan dengan rakit terapung, tentu saja rakit terapung lebih unggul dalam hal intensitas cahaya karena berhadapan langsung dengan cahaya matahari dan lambatnya kecepatan arus dan tidak bersubstrat pasir berlumpur menjadikan sistem budidaya ini jauh lebih efektif daripada sistem budidaya patok dasar.

Aslan (1998) mengatakan bahwa rumput laut memerlukan cahaya matahari 
untuk proses fotosintesisnya. Karena itu, rumput laut hanya mungkin tumbuh diperairan dengan kedalaman tertentu dimana sinar matahari sampai ke dasar perairan. Mutu dan kualitas cahaya berpengaruh terhadap produksi spora dan pertumbuhannya. Dalam penelitian ini intensitas cahaya yang paling berpengaruh besar terhadap kecepatan tumbuh Sargassum sp, karena Sargassum umumya memerlukan cahaya matahari dalam melakukan proses fotosintesis. Sargassum sp. yang ditanam pada Rakit Terapung jauh lebih banyak mendapatkan cahaya matahari daripada Sargassum sp. yang ditanam pada Patok Dasar karena berada pada permukaan laut.

Indriani (1991) menjelaskan bahwa kondisi perairan pantai tempat tumbuh rumput laut tidak boleh keruh, karena apabila kondisi perairannya keruh maka akan dapat menghalangi proses fotosintesis dari rumput laut. Air harus jernih sehingga tidak menghalangi sinar matahari menembus air laut. Selama Pelaksanaan pembudidayaan ditemukan masalah yang berpengaruh besar terhadap kecepatan tumbuh Sargassum sp. tersebut yakni, pada Patok Dasar dimana seluruh bagian permukaan dari Sargassum sp. pada semua rumpun termasuk tali budidaya tertutupi oleh lumpur, tentu saja hal ini akan menghambat proses fotosintesis karena bagian talus dan laminer daun yang seharusnya mendapatkan sinar matahari yang cukup malah terhambat oleh lumpur tersebut. Sedangkan pada Rakit Terapung lumpur sama sekali tidak ditemui pada tiap-tiap rumpun.

Romimohtarto dan Juwana menyatakan bahwa gerakan-gerakan air laut disebabkan oleh beberapa faktor, seperti angin yang menghembus diatas permukaan laut. Pengadukan yang terjadi karena perbedaan suhu air dari dua lapisan, perbedaan tinggi permukaan laut, pasang surut, dan lain-lain. Menurut Indriani (1991) bahwa arus permukaan digerakkan oleh angin. Kecepatan arus yang dianggap cukup untuk budidaya rumput laut sekitar 20-40 $\mathrm{cm} /$ detik. Dengan kondisi seperti ini akan mempermudah penggantian dan penyerapan hara yang diperlukan oleh tanaman, tetapi tidak sampai merusak tanaman. Di Teluk Ekas terdapat perbedaan kecepatan arus, dimana pada dasar perairan kecepatan arusnya jauh lebih besar daripada di permukaan perairan, hal ini menyebabkan selama pembudidayaan arus gelombang membuat Sargassum sp .tersebut lepas dari ikatannya karena terbawa oleh arus, jumlah rumpun yang hilang pada patok dasar jauh lebih banyak daripada yang ada di rakit terapung yakni 23 rumpun dinyatakan hilang sedangkan pada rakit terapung hanya 1 rumpun yang dinyatakan hilang;

Winarno (1996) menjelaskan bahwa zat hara dari kadar nitrat dan fosfat mempengaruhi stadia reproduksi alga bila zat hara tersebut melimpah diperairan. Kadar nitrat dan fosfat di perairan akan mempengaruhi kesuburan gametofit alga cokelat (Laminaria nigrescenc). Teluk Ekas merupakan salah satu tempat alami bagi habitat Sargassum sp. Untuk itu kesediaan unsur hara seperti nitrat dan fosfat tentu tersedia cukup. Ketersediaan unsur hara dipermukaan dan didasar perairan itu sama akan tetapi perbedaan kecepatan gelombang atau aruslah yang mempengaruhi tingkat penyerapan unsur hara tersebut. Tentu saja arus yang tidak tergolong cepat lebih efektif dalam kemampuan tanaman menyerap unsur haranya.

Aslan (1998) menjelaskan bahwa predator (hewan pemangsa) hewan laut seperti moluska dan ikan dapat 
mempengaruhi pensporaan alga. Hewan moluska dapat memakan spora dan menghambat pertumbuhan stadia muda alga, sedangkan hewan herbivora memakan alga sehingga merusak thalli dan akan mengurangi jumlah spora yang dihasilkan oleh alga. Patok dasar umumnya lebih rentan terhadap predator seperti moluska dan ikan herbivor karena letaknya yang didasar perairan, berbeda dengan rakit terapung yang lebih sedikit pengganggunya. Akan tetapi pada musim-musim tertentu ada kegiatan para masyarakat yang biasa melakukan perburuan kerang atau dikenal dengan istilah madak. Dalam kegiatan madak, selain masyarakat mengumpulkan kerang mereka juga memotong bagian thallus Sargassum untuk dijadikan makanan, yang jadi predatornya tentu saja manusia, dan tidak hanya itu masyarakat sekitar juga melakukan pemotongan Sargassum di area-area yang biasa dilalui oleh perahu. Hal ini karena Sargassum akan terkait oleh baling-baling mesin perahu, kegiatan ini awalnya pernah dihimbau oleh sebagian warga, akan tetapi oleh para orang-orang tua tidak direspon positif, akibatnya banyak Sargassum yang mengalami kerusakan. Untuk yang rakit terapung ditemukan beberapa spesies alga yang ikut tumbuh bersama dengan tanaman Sargassum yakni spesies dari Gillidium sp. dan Fillamenteus algae, akan tetapi alga-alga ini sebenarnya bukanlah tergolong predator atau parasit melainkan organisme ini tergolong komensalisme, bila dilihat keberadaan alga ini hanya mengurangi ruang dan jumlah unsur hara yang tersedia. Kesimpulannya intensitas cahaya inilah yang paling berpengaruh terhadap pertumbuhan dari Sargassum sp.

\section{KESIMPULAN}

Dari hasil penelitian dapat disimpulkan, bahwa pertumbuhan Sargassum sp. yang dibudidaya pada sistem rakit terapung jauh lebih cepat dibanding dengan budidaya sistem patok dasar.

\section{DAFTAR PUSTAKA}

Anggadiredja. 2006. Rumput Laut. Penebar Swadaya: Jakarta.

Anggadiredja, J.T., Zatnika, A., Purwato, H., dan Istini, S. 2008. Rumput laut, pembudidayaan, pengolahan dan pemasaran komoditas perikanan potensial. Penebar Swadaya: Jakarta.

Aslan, L. 1998. Budidaya Rumput Laut (Edisi Revisi). Kanisius : Yogyakarta.

Atmadja, W.S. dan Sulistijo. 1980. Algae Bentik Dalam : Peta Sebaran Geografik Beberapa Biota laut di Perairan Indonesia. Lembaga Oseanologi Nasional-LIPI Jakarta: 117-118.

Bold, C.H. and M.J. Wynne. 1977. Introduction the algae; Structure and repro-duction. Grentice. Hall Biologycal Sci-ences Series. India New Delhi: 706.

Boney, A. D. 1965. Aspect of the biology of the seaweeds of economic importance. Mar. Bot. 3: 205-253.

Guiry, M.D. 2007. Seasonal Growth and Phenotypic Variation in Poryphyra Linearis (Rhodophyta) populations on The West Coast of Ireland. Journal of Phycology 43 : 90-100.

Hak, N dan Tazwir. 2004. Pengaruh Umur Panen Rumput Laut Coklat (Sargassum Filipendula) Terhadap Mutu FisikoKimia Natrium Alginat Yang Dihasilkannya. Buletin Teknologi Hasil Perikanan: 80 - 89.

Indriani, H. 1991. Budidaya, Pengolahan, dan Pemasaran Rumput Laut. Penebar Swadaya : Jakarta.

Kadi, A. 2005. Kesesuaian Perairan Teluk Klabat Pulau Bangka Untuk Usaha Budidaya Rumput laut. Jour. Sci. Fish. VII (1): 65-70. 
Msuya, F.E and A. Neori. 2002. Ulva reticulata and Gracilaria crassa:macrolagae that can biofilter effluent from tidal fishponds in Tanzania. Wedtern Indian Ocean J. Mar. Sci. 1(2): 117-126.

Rachmat, R. 1999. Kandungan dan Karakteristik Fisiko Kimia Alginat dari Sargassum sp. yang Dikumpulkan dari Perairan Indonesia. Lanoratorium Produk Alam Laut, Puslitbang Oseanologi LIPI. Jakarta: 9.

Romimohtarto, K. dan Juwana, S. 2001. Biologi Laut. Ilmu Pengetahuan Tentang Biota Laut. Jakarta.

Winarno, 1996. Teknik Pengolahan Rumput Laut. Pustaka Sinar Harapan: Jakarta. 